Disertacije • Dissertations

Matjaž Barbo

\title{
Pro musica viva Prispevek k slovenski moderni po II. svetovni vojni
}

Nova glasba 20. stoletja je poudarila pomen kompozicijsko-tehničnih novosti in jih povzdignila na raven estetskih kategorij. Tudi zgodovinopisje, oblika periodiziranja slogovnih premen, se je v 20. stoletju z nastopom modernizma opirala na kompozicijsko-tehnične zasuke, ne pa na globalne spremembe filozofske paradigme in z njo povezane estetske obrate. Izključnostno pravico do opredeljevanja slogovnih prvin so dobile kompozicijsko-tehnične poteze, na katere se je posledično vezal tudi filozofski premislek.

Petdeseta in šestdeseta leta $\mathrm{v}$ slovenski glasbi bi lahko podobno kot drugje $\mathrm{v}$ Evropi označili kot obdobje "novega začetka", leta "nič". Mladi skladatelji, ki so se $\mathrm{v}$ teh letih začeli predstavljati javnosti, so najavljali novo generacijo glasbenikov. Tuja so jim bila populistična socrealistična načela, ki jih je aktualna politična ideologija po 2. svetovni vojni postavljala za merodajne estetske norme. Novi rod glasbenikov se jim je zoperstavil in oblikoval novo modernistično estetiko, ki je znova zagovarjala normative glasbene avtonomnosti.

Mladi skladatelji so se po končanem študiju čutili zapostavljen. Bili so prepričani, da je bilo bistveno premalo priložnosti za izvedbe njihovih del, perspektive posameznikov pa niso bile spodbudne. Ker so imeli že nekaj izkušenj s sorodnimi skladateljskimi združenji, so tisti, ki so tvorili najbolj avantgardno jedro skladateljskega rodu, na začetku šestdesetih let ustanovili skupino Pro musica viva. Čeprav je bil temeljni razlog za povezovanje skladateljev afirmacija njihovih del, pa je moralo njihovo združenje - da bi bilo navzven prepričljivo - temeljiti na vsaj delno enovitem skupnem estetskem imenovalcu. Formula, ki so se je ob ustanovitvi skupine oklenili, je v Osnutku statuta skupine izražena z naslednjimi besedami: "Stilna in estetska usmeritev članov je svobodna, toda s pogojem, da je sodobna." 
Pisati "sodobno" je kot povezovalni temelj pomenilo zavračati kompozicijskotehnične postulate starejših kolegov, "sodobni" jezik pa je bil v pogojih estetike Novega conditio sine qua non prepričljivejšega in umetniško vrednejšega glasbenega jezika.

Osrednji programski cilji skupine PMV so bili troji: uveljaviti "sodobno" slovensko glasbo (predvsem skladbe članov skupine), predstaviti "sodobne" tuje tokove in v glasbeni zavesti obuditi slovensko zgodovinsko avantgardo. Skupina se je predstavila s široko razvejano dejavnostjo: organizirali so koncerte in pogovore, izdajali muzikalije, se predstavljali na radiu in televiziji ipd. Člani so se zbirali v zaprtem krogu, kjer so pripravljali javne nastope ter skupaj poslušali posnetke skladb in študirali partiture. To je bil tudi prostor intenzivnih pogovorov o bistvenih estetskih vprašanjih, skladatelji so spoznavali in polemično soočali različne kompozicijske koncepte, razpravljali o kompozicijsko-tehničnih vprašanjih itn. Redno druženje in skupno spoznavanje aktualnih kompozicijskih tokov je verjetno vplivalo tudi na to, da lahko $\mathrm{v}$ delih več skladateljev istočasno zasledimo enake kompozicijsko-tehnične poteze, ki sledijo kronološkemu zaporedju uveljavljajočega se Novega v evropski glasbi.

Ob koncu delovanja skupine so si bili skladatelji kompozicijsko-tehnično povsem vsaksebi. Vsak od njih je izdelal lastno poetiko, svojo kompozicijsko tehniko. "Sodobnost" kompozicijskega jezika so uresničevali na tako različnih ravneh, da ni bilo med njimi nobene enovitosti več. Hkrati s tem so se od sredine šestdesetih let člani skupine vse bolj uveljavljali v slovenski glasbeni javnosti in si enakovredneje delili prostor s starejšimi kolegi. Tudi s tem so izgubljali veljavo temeljni razlogi za njihovo povezovanje. Logična posledica vsega je bila, da je skupina razpadla.

Skupina Pro musica viva je gotovo pomembno vplivala na temeljni estetski premik v slovenski glasbi poznih petdesetih in šestdesetih let. Pomemben ni le neposredni premik v Novo, kot ga lahko opazujemo v skladbah njenih članov v letih delovanja skupine, ampak tudi posredni vpliv, ki ga je imela skupina na oblikovanje javnega mnenja.

Obranjeno 17. aprila 1997 na Filozofski fakulteti v Ljubljani. 


\section{Pro musica viva \\ A Contribution to Slovenian Modern Trends since World War II}

The new music of the 20th century stressed the significance of compositional-technical novelties and raised them to the level of aesthetic categories. In the present century also bistoriography, a form of identifying stylistic changes according to periods, with the emergence of modernism, relied on compositional-technical turns rather than on global shifts in the philosopbical paradigm and on aesthetic changes related to it. The exclusive right to determining stylistic elements was passed on to compositional-technical features to which philosophical reflection was related as a consequence.

The fifties and the sixties in Slovenian music could be, like elsewhere in Europe, marked as a period of "new beginnings", of the year "zero". Young composers who were in these years presenting themselves to the public were announcing a new generation of musicians. They found as alien the populist principles of socialist realism, which the political ideology current after World War II was setting up as determining aesthetic norms. The new generation of musicians set itself against them and started shaping a new modernist aesthetics again pleading for the norms of musical autonomy.

Young composers, having concluded formal musical studies, felt ignored. They believed that there was virtually too little opportunity for the production of their works, and the prospects of individuals were not stimulating. Having had already some experience with the related professional associations, those among them who formed the most avantgarde nucleus in the generation of composers, coming up at the beginning of the sixties, founded the group Pro musica viva. Although the principal reason for the interaction of the composers was the affirmation of their works, their association - in order to be convincing to the outside environment - had to be based at least on a partly unified aesthetic denominator. The formula espoused when founding the group is in the Draft of the Statute expressed in the following words, "The stylistic and aesthetic orientation of members is free, but on condition that it is modern". To write "in a modern way" denoted as an integrating basis the rejection of the postulates of elderly colleagues, while the "modern" language was in the conditions of the aesthetics a conditio sine qua non of what was new more convincing and artistically more valuable musical language.

The central programme aims of the group were three: to win recognition for the "modern" Slovenian music (particularly compositions by members of the group), to present "modern" foreign trends, and in the musical conscience to awake the Slovenian bistoric avantgarde. The group was presenting itself with a widely ramified activity: they organised concerts and talks, issued musical publications, ap- 


\section{MUZIKOLOŠKI ZBORNIK • MUSICOLOGICAL ANNUAL XXXIV}

peared on the radio and television, etc. The members met in a closed circle where they prepared public appearances, jointly listened to recordings of compositions and studied the scores. This was likewise the place for intensive talks about essential aesthetic issues, the composers became acquainted and polemically confronted with different compositional concepts, they discussed compositional-technical points, etc. Regular meetings and learning about topical compositional trends possibly account for the fact that in the works by several composers we can simultaneously trace the same compositional-technical features, which in a chronological sequence follow the advancing new elements in European music.

At the end of their activity the composers from this group went in compositionaltechnical respects wholly apart. Each of them made for himself his own poetics, bis own compositional technique. The "modern quality" of the compositional language was being realised by them at such different levels that no unity has been left. At the same time, since the mid-sixties, members of the group were increasingly becoming established in the Slovenian musical public and more on equality terms performed on the concert stage with elderly colleagues. This again diminished the value of the basic reasons for their association. It was a logical consequence of it all that the group broke up.

The group Pro musica viva meant a significant avantgarde nucleus of the aesthetic shift in Slovenian music in the late fifties and in the sixties. Significant is not only the direct shift into the new music, as it can be observed in the compositions by their members during the years of the group's activity, but also the indirect influence which the group had on the shaping of public opinion.

Defended on April 17, 1997, Philosopbical Faculty, Ljubljana. 